\title{
Comparison of Some Morphological Features, Quality and Chemical Content of Four Cultivars of Chokeberry Fruits (Aronia melanocarpa)
}

\author{
Ireneusz OCHMIAN ${ }^{1 *}$, Józef GRAJKOWSKI ${ }^{1}$, Miłosz SMOLIK² \\ ${ }^{1}$ West Pomeranian University of Technology in Szczecin, Department of Pomology, Stowackiego 17, 71 - \\ 434 Szczecin, Poland; ireneusz.ochmian@zut.edu.pl ('correspondingauthor) \\ ${ }^{2}$ West Pomeranian University of Technology in Szczecin, Department of Plant Genetics, \\ Breeding and Biotechnology, Stowackiego 17, 71-434 Szczecin, Poland
}

\begin{abstract}
Two cultivars of chokeberry - 'Nero' and Polish 'Galicjanka' are sold in Poland. Sometimes, there are also present the seedlings of 'Viking' and 'Hugin' cultivars. In the experiment some morphological characteristics, the quality of fruits and chemical composition of four chokeberry cultivars ('Galicjanka, 'Hugin', 'Nero,' 'Viking') were compared. Chokeberry plants were grown at the Experimental Station of Pomology Department at the West Pomeranian University of Technology in Szczecin. Fruits collected from 'Hugin' cultivar shrubs were the smallest (100 fruits weight was $32 \mathrm{~g}$ ) and the least juice was obtained from them (73.6\%); however, they were characterised by the highest content of soluble solids $\left(18.7^{\circ} \mathrm{Bx}\right)$, titratable acids $(1.05 \mathrm{~g})$, polyphenols $(2340 \mathrm{mg})$, especially cyanidin 3-galactoside as well as nitrates $(98.5 \mathrm{mg})$ and nitrites $(1.87 \mathrm{mg})$. The 'Hugin' cultivar was characterised by light-coloured fruits, and, as a result, by lightcoloured juice. Fruits of 'Galicjanka' cultivar were the biggest, 100 fruits weight was 111,7 g. In fruits of the 'Nero' and 'Viking' cultivars, the content of individual components was at the lowest level. These cultivars have the largest amount of substances colouring fruits, pulp as well as red and blue juices, are also the darkest and the dark juice was obtained from them. Maceration of fruit pulp resulted in a significant change of colour of the juice obtained, it become darker and had a more intense blue colour.
\end{abstract}

Keywords: chemical composition, colours, firmness, fruits quality, gloss, maceration, phenolic compounds

\section{Introduction}

Chokeberry (black chokeberry) is a species with lower cultivation requirements within Rosaceae family and is an indigenous species in eastern North America and East Canada. More recently it is cultivated also in East European countries and Germany (Jeppsson, 2000a, 2000b; Strigl et al., 1995). Black-fruited (Aronia melanocarpa), red-fruited ( $A$. arbutifolia) and purple-fruited ( $A$. prunifolia) chokeberries are three cultivars growing in the wild. In the beginning of the $20^{\text {th }}$ century, chokeberry was transferred to Russian botanic gardens, where it spread in the European part of the country. Health benefits of chokeberry were appreciated quite quickly and plantations were established there (Seidemann, 1993). From there, it spread to the Central and Eastern European countries, where it is currently planted on a large scale (Benvenuti et al., 2004). In Poland, chockeberry shrubs meant for fruit production were introduced in the seventies (Kleparski and Domino, 1990).

The Aronia shrubs can grow to a height of 2-3 m, which produce in May to June umbels of some 20-30 small white flowers, ripening to purplish black berries of a diameter of 6-13 $\mathrm{mm}$ and a weight of 0.5-2 g (Ara, 2002; Seidemann, 1993). Aronia is cold and hardy to about $-30^{\circ} \mathrm{C}$ and is not sensitive to spring frost due to the late flowering time. The fruit is high in sugar (12-20\% soluble solids), has a 0.7 to $1.4 \%$ titratable acidity (Jeppsson and Johansson, 2000; Krawiec, 2008; Oszmiański and Sapis, 1988). Chokeberries have a very high content of polyphenols (Benvenuti et al., 2004; Walther and Schnell, 2009), namely phenolic acids, proanthocyanidins, anthocyanins (560-1050 mg, $100 \mathrm{~g}$ fresh weight), flavonols and flavanones (Koponen et al., 2007). In comparison with other fruit species, relatively high values of antioxidant capacity were reported in chokeberry fruit (Kulling and Rawel, 2008; Skupień and Oszmiański, 2007). High contents of cyanidin-3-arabinoside, cyanidin-3-galactoside are also typical of chokeberries (Rop et al., 2010), gnthocyanins (Espin et al., 2000; Wilska-Jeszka et al., 1991).

The fruit color reflects the type and quantity of color compounds. It is an important feature of their quality and attractiveness, and consumers search for products of intensive and natural color for a given article. It is also a characteristic feature of a variety. The aronia juice color is wine red to dark purple. Anthocyanins are red pigments present mostly in berry fruits. They give an attractive color to preserves and thus, they are frequently applied in the coloring of groceries. They are natural pigments and their addition to food does not raise consumer concern. Moreover, they have pro-healthy properties (Konczak and Zhang, 2004). 
254

Anthocyanin pigments are sensitive to the action of external factors, such as light, high temperature, acidity, and the presence of oxygen. In order to describe color quality, CIE $\mathrm{L}^{*} \mathrm{a}^{*} \mathrm{~b}^{*}$ system is frequently applied. It is a system of color description that was elaborated by the International Commission on Illumination (Commission Internationale d'Eclairage) in 1976.

Chokeberry fruits are used in the production of jams, preserves, juices, cordials and as a natural colorant of food products (Jeppsson and Niklas, 1998; Plocharski and Zbroszczyk, 1989). Chokeberries are small, dark violet fruits but - because of their astringency - are not favoured as 'table fruits'. In Poland, chokeberries are grown mainly for juice production. Although chokeberry fruits belong to the so-called soft fruits, they are exceptionally durable and resistant to damage in transportation. They may be stored in a cold store even for a few weeks after crop, without losing their biological value.

Some cultivars are bred of true black chokeberry (Aronia melanocarpa) and some are hybrid cultivars ('Stewart', 'Burka', 'Titan') (e.g. Aronia $\times$ Sorbus) (Jeppsson, 2000b; Jeppsson and Johansson, 2000). The more important cultivars include 'Nero' (the Czech Republic), 'Rubina' (crossing from Russian and Finnish plants), 'Viking' and 'Kurkumäcki' (Finland), 'Hugin' (Sweden), 'Fertödi' (Hungary) and 'Aron' (Denmark) (Strigl at al., 1995).

Generally, in Poland, two cultivars of chokeberry are sold, namely: 'Nero' and Polish 'Galicjanka.' Sometimes, there are also present the seedlings of 'Viking' and 'Hugin' cultivars. Seedlings of different origin are sold, that generally do not differ in terms of appearance and use value. Plants of undefined variety, of which commercial plantations were established, were sold for years. Due to this fact, numerous planters are of the opinion that cultivars offered by arborists do not significantly differ among each other. This was the reason for the initial genetic study performed in order to describe the range of genetic variability exist between selected genotypes of Aronia (Smolik et al., 2011). The aim of the study was to compare some morphological features, quality, and chemical content of four cultivars of chokeberry fruits.

\section{Materials and methods}

\section{Materials}

Four cultivars of black chokeberry (Aronia melanocarpa (Michx.) Elliot.): including 'Galicjanka,' 'Hugin', 'Nero' and Viking' were used in this study. Chokeberry plants were grown in the Experimental Station of the West Pomeranian University of Technology in Szczecin in Rajkowo and Ostoja near Szczecin (north-west Poland). The plantation was established on grey-brown podsolic soil originated from medium boulder clay. The experiment was carried out in 2007. The fertilization with nitrogen in two doses, $40 \mathrm{~kg}$ N.ha- ${ }^{-1}$ each, was used whereas, phosphorus and potassium fertilization was not applied because the soil was abundant in these elements $(7.3 \mathrm{mg} \cdot 100 \mathrm{~g}$ and $48.0 \mathrm{mg} \cdot 100 \mathrm{~g}^{-1}$, respectively). The $\mathrm{pH}$ was neutral (6.8-7.1). From florescence to harvest, drip irrigation was performed according to tensiometer indications. Because Aronia melanocarpa plants are resistant to pathogen diseases 'by nature' no chemical protection was applied. The fruits were collected in full ripeness stage in September.

\section{Methods}

Physical features of fruits were measured on fresh berries immediately after the harvest. Dry weight, soluble solids, titratable acidity, total sugar, reducing sugar, nitrate and nitrite content, were performed on fresh fruits packed in polyethylene bags and stored overnight at $5^{\circ} \mathrm{C}$. The weight of 100 fruit was expressed in grams. The fruit diameter and firmness was measured by means of nondestructive device FirmTech2 combined with a computer (BioWorks, USA). The firmness of 100 randomly selected berries from every replicate was expressed as a gram-force causing fruit surface to bend $1 \mathrm{~mm}$. For juice extraction efficiency fruit were homogenized with a blender and heated up to $50^{\circ} \mathrm{C}$. Then, after cooling, $1.5 \mathrm{ml}$ of pectinase (Rapidaza Super) per $500 \mathrm{~g}$ of pulp were added. The pulp was left to stand in a room temperature for 1 hour. Afterward, the pulp was pressed for $10 \mathrm{~min}$ at the final pressure of 300 $\mathrm{kPa}$ by means of a laboratory hydraulic press (Oszmiański and Wojdylo, 2005).

Dry weight of fruit was determined with a gravimetric method (drying an aliquot $\sim 5 \mathrm{~g}$ of fruit tissue at $105^{\circ} \mathrm{C}$ to constant weight) according to Polish standard (PN) (PN-90/A-75101/03).

Soluble solids content was determined with a digital refractometer PAL-1 (Atago, Japan).

Titratable acidity was determined by titration of a water solution of chokeberry homogenate with $0.1 \mathrm{~N} \mathrm{NaOH}$ to an end point of $\mathrm{pH} 8.1$ (measured with an multimeter Elmetron CX-732) according to PN-90/A-75101/04.

Total sugar and reducing sugar content was determined according to the Loof-Schoorl method.

Sucrose content was calculated according to the relationship: sucrose $=($ total sugar - reducing sugar $) \times 0.95$. Nitrate and nitrite content was measured with a RQflex 10 requantometer (Merck) and expressed as mg per 100 $\mathrm{g}$ fruit juice.

Total polyphenol content in the methanol (70\%) extracts was estimated according to Singleton and Rossi (1965) with the Folin-Ciocalteu reagent. The data is expressed as mg of gallic acid equivalents (GAE) per $100 \mathrm{~g}$ of fruit tissue.

Phenolics composition of blueberries was determined in fruit samples that were kept frozen $\left(-32^{\circ} \mathrm{C}\right)$ in polyethylene bags $(250-300 \mathrm{~g})$ until analyzed. The $2 \mathrm{~g}$ aliquots of fruit (after thawing) were extracted three times with $\sim 8 \mathrm{~mL}$ of $80 \% \mathrm{MeOH}$ acidified with a glacial acetic acid $(1 \mathrm{ml}$ of $100 \%$ acetic acid per $1180 \% \mathrm{MeOH}$ ) in an ultrasonic bath for $15 \mathrm{~min}$. The samples were filtered and transferred to 
the flasks and made up to the final volume $25 \mathrm{ml}$. Further, the extracts were centrifuged twice at $12,000 \mathrm{~g}$ and $20 \mu \mathrm{l}$ of supernatants were injected into the HPLC system. The HPLC apparatus consisted of a Merck-Hitachi L-7455 diode array detector (DAD) and quaternary pump L-7100 equipped with D-7000 HSM Multisolvent Delivery System (Merck-Hitachi, Tokyo, Japan). The separation was performed on a Cadenza CD C18 $(75 \times 4.6 \mathrm{~mm}, 5 \mathrm{~mm})$ column (Imtakt, Japan). Column oven temperature was set at $30^{\circ} \mathrm{C}$. The mobile phase was composed of solvent $\mathrm{A}$ (4.5\% formic acid, $\mathrm{pH} 2.2$ ) and solvent B (acetonitrile). The program began with a linear gradient from $0 \% \mathrm{~B}$ to $21 \% \mathrm{~B}(0-30 \mathrm{~min})$, followed by washing and reconditioning the column. The flow rate was $1 \mathrm{ml} \mathrm{min}{ }^{-1}$ and the runs were monitored at the following wavelengths: phenolic acids at $320 \mathrm{~nm}$, flavonol glycosides (quercetin and kaempferol derivatives) and luteolin at $360 \mathrm{~nm}$, and anthocyanin glycosides at $520 \mathrm{~nm}$ (Fig. 1). The Photo Diode Array spectra were measured over the wavelength range $200-600 \mathrm{~nm}$ in steps of $2 \mathrm{~nm}$. Retention times and spectra were compared to those of pure standards within 200-600 $\mathrm{nm}$. Standards of anthocyanidin glycosides were obtained from Polyphenols Laboratories (Norway), flavonols, and phenolic acids from Extrasynthese (France).

Greening index determined using Chlorophyll Meter SPAD- 502 (Minolta) in SPAD units in autumn, a measurement of leaf surface was performed by means of a DIAS scanner connected to a computer.

Fruit color and shine, juice and pulp color were measured in a transmitted mode through Konica Minolta CM-700d spectrophotometer in $1 \mathrm{~cm}$-thick glass trays. Measurements were conducted in CIE $\mathrm{L}^{*} \mathrm{a}^{*} \mathrm{~b}^{*}$ system, through a $10^{\circ}$ observer type and D65 illuminant. Statistical analysis was done by using Statistica software package version 8.1 (Statsoft, Poland). The data were subjected to one-way analysis of variance. Values of $p<0.05$ according to Duncan multiple comparison test for physical features estimation were considered significant.

\section{Results and discussion}

On the basis of the results obtained. different sizes of chokeberry fruit cultivars were observed (Tab. 1). Fruits of 'Galicjanka' variety had the highest weight of 100 fruits and the longest diameter. Fruits picked up from 'Hugin' variety bushes were significantly smaller. The weight of 100 fruits amounted to only $32 \mathrm{~g}$. whereas the fruits of 'Galicjanka' variety was $111.7 \mathrm{~g}$.

According to Jeppsson (2000 b and a) the fruits of Galicjanka,' 'Nero' and 'Viking' cultivars may be considered large fruits. These cultivars weighed from 65 to almost 95 g. In specific years of research by Kawecki and Tomaszewska (2006), the weight of cropped fruits ranged from 84 to 98 g. In turn Smolarz and Chlebowska (1997) and Strik et al. (2003) obtained fruits that weighed about $280 \mathrm{~g}$.

A relationship between the fruit size and ripeness was observed. Small fruits of 'Hugin' variety were the ripest. These fruits showed also the lowest juice efficiency. Similar amount of juice was obtained from the other fruit cultivars -'Galicjanka' and 'Nero'. They equaled $76.8 \%$ and $78.9 \%$. respectively. Fruit efficiency from control plants achieved by Skupien et al. (2008) obtained in an experience reached $86 \%$.

Tab. 1. Size ripeness and juice efficiency of chokeberry cultivars under study

\begin{tabular}{ccccc}
\hline \multirow{2}{*}{ Characteristics $^{\mathrm{a}}$} & \multicolumn{3}{c}{ Cultivars } \\
\cline { 2 - 5 } & 'Galicjanka' & 'Hugin' & 'Nero' & 'Viking' \\
\hline Weight of 100 fruits $(\mathrm{g})$ & $111.7 \mathrm{c}^{\mathrm{a}}$ & $32.0 \mathrm{a}$ & $91.7 \mathrm{~b}$ & $99.5 \mathrm{bc}$ \\
Fruit size $(\mathrm{mm})$ min-max & $12.9-16.4$ & $6.1-7.2$ & $12.1-15.8$ & $12.8-16.2$ \\
\hline Mean & $14.9 \mathrm{c}$ & $6.6 \mathrm{a}$ & $14.1 \mathrm{~b}$ & $14.4 \mathrm{bc}$ \\
Firmness $\left(\mathrm{G} \cdot \mathrm{mm}^{-1}\right)$ min-max & $309-548$ & $384-674$ & $338-586$ & $327-572$ \\
\hline Mean & $411 \mathrm{a}$ & $489 \mathrm{c}$ & $445 \mathrm{~b}$ & $453 \mathrm{~b}$ \\
\hline Juice extraction efficiency $(\%)$ & $76.8 \mathrm{~b}$ & $73.6 \mathrm{a}$ & $78.9 \mathrm{~b}$ & $77.2 \mathrm{~b}$ \\
\hline
\end{tabular}

${ }^{a}$ Mean values marked with the same letter do not differ significantly at $p=0.05$ according to Duncan's multiple range test
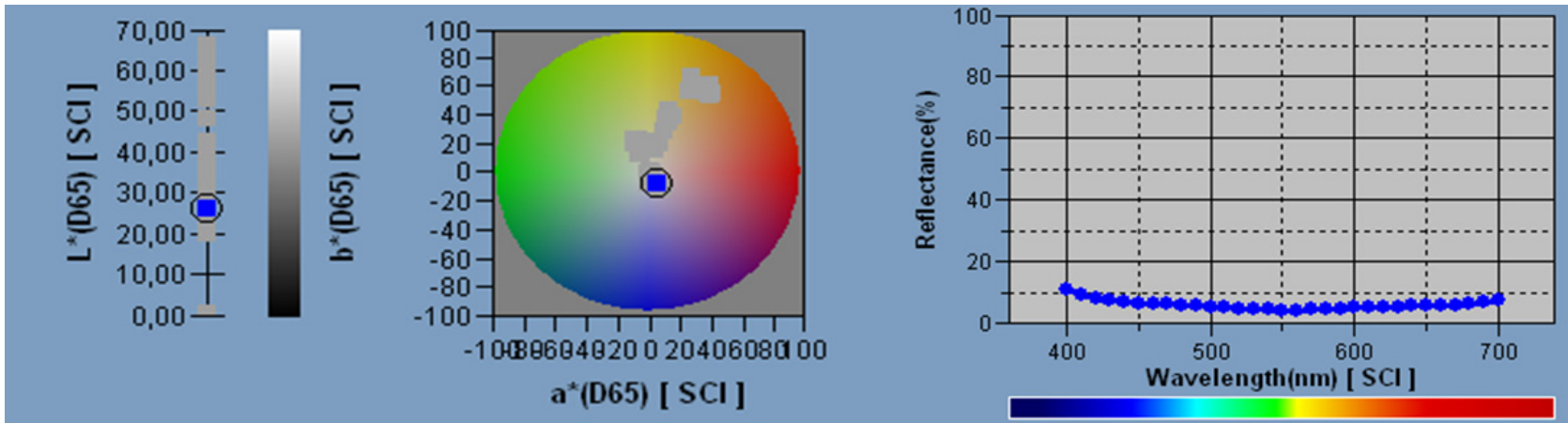

Fig. 1. CIE $L^{*} a^{*} b^{*}$ chromaticity diagram $-L^{*}(100$ white, 0 black $) a^{*}(-100$ yellow, +100 blue $) b^{*}(-100$ red,+100 green $)$ 
256

The analysis of the chokeberry cultivars under study indicated different fruit chemical content (Tab. 2 and 3). Generally the highest content of a majority of the discussed ingredients was present in the fruits of the 'Hugin' variety (Tab. 2). The chemical content of the fruits of 'Nero' and 'Viking' cultivars was similar and the content of specific ingredients was on a lower level.

In the case of these cultivars, the dry matter content constituted $15.7 \%$ and $15.3 \%$ and in the fruits of the 'Hugin' variety it equaled as much as $19.5 \%$. The dry matter content of berries ranges from $17 \%$ to $30 \%$ (Lehmann, 1990; Skupień and Oszmiański, 2007). The soluble solid content was on a similar level. In the fruits of 'Nero' and 'Viking' cultivars it amounted to $14.4^{\circ} \mathrm{Bx}$ and $14.2^{\circ} \mathrm{Bx}$ respectively. The highest content $\left(18.7^{\circ} \mathrm{Bx}\right)$ characterized the fruits of the 'Hugin' variety. The soluble solid content in chokeberries depends upon numerous factors: weather. environmental conditions. crop period. and variety. and it amounts from 12.4 to $18.3 \%$ (Jeppsson $2000 \mathrm{a}$ and b; Strik et al., 2003).

Chokeberry fruits have generally a low organic acid content that equals from 1 to $1.5 \%$ (Lehmann, 1990; Tanaka and Tanaka, 2001; Skupień et al., 2008). The main acids identified were L-malic acid and citric acid. The fruits under study were characterized by a lower organic acid content; in the 'Galicjanka' variety, it was at the level of $0.75 \mathrm{~g}$ in 100 grams of fruits.

No significant differences in the total and reduced sugar content were detected (Tab. 2). The total sugar content estimated in this experiment (6.2-10.8 g in 100 grams of fruits) was similar to the data reported by Kleparski and Domino (1990). The level of reduced sugar in the analyzed fruits ranged from $8.83 \mathrm{~g}$ ('Viking') to $12.48 \mathrm{~g}$ ('Hugin'). The content of reducing sugar in fresh chokeberries was found to be between 16-18\% (Strigl et al., 1995). According to Seidemann (1993) the sum of glucose and fructose was determined to lie between 13.0-17.6 g.100 g $\mathrm{g}^{-1} \mathrm{FW}$.

The highest level of harmful nitrates and nitrites was detected in the fruits of 'Hugin' variety (Tab. 2). The nitrate content was more than twice higher than in the fruits of 'Nero' variety and the nitrite content was three times higher than in the fruits of 'Viking' variety. In Poland and other countries there is a lack of regulations on permissible nitrate content in fruits (except for bananas). According to the Polish Ministry of Agriculture (Dz. U. 2003) the permissible nitrate content in vegetables meant for feeding babies and young children should not exceed $200 \mathrm{mg}$ $\mathrm{NaNO}_{3} \mathrm{~kg}^{-1}$.

A scientifically confirmed positive influence of polyphenols on health demands strives to maintain these compounds both in fruits and preserves as efficiently as possible. In the case of chokeberry the juice is also to be considered. Chromatographic (HPLC) and GAE analyses showed that chokeberry fruits are a rich source of polyphenols especially those of 'Hugin' variety. Total polyphenols (GAE) amounted to $2340 \mathrm{mg}$ gallic acid per $100 \mathrm{~g}$ (Tab. 2) and that determined by means of the HPLC equaled $1329 \mathrm{mg}$ (Tab. 3). The total polyphenols of freshly produced products were in the range of $6144-6188 \mathrm{mg} \cdot \mathrm{l}^{-1}$ and the anthocyanin content (HPLC) between 1035-1160 mg. ${ }^{-1}$ (Würth et al., 2010). Jakobek et al. (2007) obtained a higher amount of total phenol for chokeberry (7194 $\left.\mathrm{mg} \cdot \mathrm{kg}^{-1}\right)$. The total phenolic content of Aronia berries cultivar 'Nero' has been determined to range from 3440-3760 mg. $100 \mathrm{~g}^{-1}$ of DW (Hudec et al., 2006; Kolesnikov and Gins, 2001) to $4210 \mathrm{mg} 100 \mathrm{~g}^{-1}$ of DW of berries cultivar 'Viking' (Kähkönen et al., 1999, 2001).

Cyanidin 3-galactoside constituted a majority of the polyphenols determined (Tab. 3). It made up 50\% of the determined phenolic compounds in all the cultivars under study. This compound was determined at a similar level in the previous research (Ochmian et al., 2009). Also other authors confirm a high cyanidin 3-galactoside content in the analyzed chokeberry fruits (Jeppsson and Johansson, 2000) which amounted from $237 \mathrm{mg}$ (Zheng and Wang, 2003) to $990 \mathrm{mg}$ (Wu et al., 2004).

The color of the analyzed fruits and juices obtained thereof was measured in a transmitted mode determined by means of the photocolorimetric method conducted in CIE L*a*b* system (Tab. 4 and 5).

The $\mathrm{a}^{*}$-value providing information of the position in the color gamut between green and red (Fig. 1) measured

Tab. 2. Chemical composition of chokeberry fruit

\begin{tabular}{|c|c|c|c|c|}
\hline Traits & 'Galicjanka' & 'Hugin' & 'Nero' & 'Viking' \\
\hline Dry weight (\%) & $17.80 \mathrm{~b}^{\mathrm{a}}$ & $19.50 \mathrm{c}$ & $15.70 \mathrm{a}$ & $15.30 \mathrm{a}$ \\
\hline Soluble solids ( $\left.{ }^{\circ} \mathrm{Bx}\right)$ & $16.60 \mathrm{~b}$ & $18.70 \mathrm{c}$ & $14.40 \mathrm{a}$ & $14.20 \mathrm{a}$ \\
\hline $\begin{array}{l}\text { Titratable acidity } \\
\left(\text { g citric acid } 100 \cdot \mathrm{g}^{-1}\right)\end{array}$ & $0.75 a$ & $1.05 b$ & $0.85 \mathrm{a}$ & $0.80 \mathrm{a}$ \\
\hline Total sugar (g 100.g $\left.\mathrm{g}^{-1}\right)$ & $12.92 \mathrm{a}$ & $13.79 a$ & $10.25 \mathrm{a}$ & $9.16 \mathrm{a}$ \\
\hline Reducing sugar $\left(\mathrm{g} 100 \cdot \mathrm{g}^{-1}\right)$ & $12.16 \mathrm{a}$ & $12.48 \mathrm{a}$ & $9.88 \mathrm{a}$ & $8.83 a$ \\
\hline Nitrate $\left(\mathrm{mg} \cdot \mathrm{kg}^{-1}\right)$ & $62.70 \mathrm{a}$ & $98.50 \mathrm{~b}$ & $45.20 \mathrm{a}$ & $53.80 \mathrm{a}$ \\
\hline Nitrite $\left(\mathrm{mg} \cdot \mathrm{kg}^{-1}\right)$ & $1.24 \mathrm{~b}$ & $1.87 \mathrm{c}$ & $0.84 \mathrm{a}$ & $0.62 \mathrm{a}$ \\
\hline $\begin{array}{c}\text { Total polyphenol } \\
\text { (mg gallic acid per } 100 \mathrm{~g})\end{array}$ & $2185 b$ & $2340 c$ & $1950 \mathrm{a}$ & $1845 \mathrm{a}$ \\
\hline
\end{tabular}

${ }^{a}$ Explanation was displayed in Tab. 1 
Tab. 3. Phenolic compounds pattern of chokeberry fruit (mg.100 $\left.\mathrm{g}^{-1}\right)$

\begin{tabular}{|c|c|c|c|c|}
\hline $\begin{array}{ll}\text { Items } & \text { Cultivars } \\
\end{array}$ & 'Galicjanka' & 'Hugin' & 'Nero' & 'Viking' \\
\hline Chlorogenic acid & 84.0 & 96.6 & 75.2 & 72.0 \\
\hline Neochlorogenic acid & 79.1 & 59.3 & 67.8 & 62.2 \\
\hline Nonidentified phenolic acid (r.t. $16.4 \mathrm{~min}$ ) & 13.9 & 18.0 & 8.4 & 7.1 \\
\hline Nonidentified phenolic acid (r.t. $35.4 \mathrm{~min}$ ) & 87.3 & 116.1 & 85.6 & 72.5 \\
\hline Quercetin 3-rutinoside & 5.5 & 3.9 & 3.9 & 6.1 \\
\hline Quercetin 3-galactoside & 9.9 & 7.9 & 6.6 & 9.1 \\
\hline Quercetin 3-glucoside & 7.1 & 11.3 & 6.4 & 4.4 \\
\hline Quercetin 3-vicianoside & 3.3 & 4.3 & 3.1 & 2.6 \\
\hline Quercetin 3-robinobioside & 5.7 & 11.3 & 2.1 & 1.1 \\
\hline Cyanidin 3-galactoside & 512.9 & 636.0 & 436.3 & 417.3 \\
\hline Cyanidin 3-glucoside & 18.2 & 27.2 & 10.7 & 7.8 \\
\hline Cyanidin 3-arabinoside & 249.5 & 299.4 & 133.8 & 128.0 \\
\hline Cyanidin 3-xyloside & 33.2 & 38.2 & 30.4 & 29.0 \\
\hline Total & $1109.4 b^{a}$ & $1329.5 \mathrm{c}$ & $870.3 \mathrm{a}$ & $819.2 \mathrm{a}$ \\
\hline
\end{tabular}

${ }^{a}$ Explanation was displayed in Tab. 1

Tab. 4. Fruit and pulp color and gloss of the chokeberry cultivars under study

\begin{tabular}{|c|c|c|c|c|c|c|c|}
\hline \multirow{2}{*}{ Cultivars } & \multicolumn{3}{|c|}{ Fruit color } & \multirow{2}{*}{ Gloss fruits } & \multicolumn{3}{|c|}{ Pulp color } \\
\hline & $\mathrm{L}^{*}$ & $a^{*}$ & $b^{*}$ & & $\mathrm{~L}^{*}$ & $a^{*}$ & $\mathrm{~b}^{*}$ \\
\hline 'Galicjanka' & $18.94 \mathrm{~b}^{\mathrm{a}}$ & $4.46 \mathrm{ab}$ & $-1.32 \mathrm{a}$ & $3.81 \mathrm{c}$ & $24.90 \mathrm{a}$ & $13.94 \mathrm{~b}$ & $-4.87 \mathrm{a}$ \\
\hline 'Hugin' & $21.59 \mathrm{c}$ & $2.44 a$ & $-4.59 \mathrm{ab}$ & $2.34 \mathrm{~b}$ & $35.84 \mathrm{c}$ & $9.48 \mathrm{a}$ & $-7.59 b$ \\
\hline 'Nero' & $16.62 \mathrm{a}$ & $5.47 \mathrm{ab}$ & $-6.04 b c$ & $0.68 \mathrm{a}$ & $30.05 b$ & $22.00 \mathrm{c}$ & $-10.61 b$ \\
\hline 'Viking' & $16.14 \mathrm{a}$ & $7.51 \mathrm{~b}$ & $-8.89 c$ & $0.73 a$ & $31.11 \mathrm{~b}$ & $21.08 \mathrm{c}$ & $-10.84 \mathrm{~b}$ \\
\hline Mean & $18.32 \mathrm{~A}$ & $4.97 \mathrm{a}$ & $-5.21 \mathrm{a}$ & & $30.48 \mathrm{~B}$ & $16.63 \mathrm{~b}$ & $-8.48 \mathrm{a}$ \\
\hline
\end{tabular}

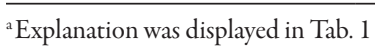

Tab. 5. Juice and pomace color after maceration period of the chokeberry cultivars under study

\begin{tabular}{|c|c|c|c|c|c|c|c|c|c|c|c|c|}
\hline \multirow{3}{*}{ Cultivars } & \multicolumn{6}{|c|}{ Juice color } & \multicolumn{6}{|c|}{ Pomace color } \\
\hline & \multicolumn{3}{|c|}{$1 \mathrm{~h}$ after maceration } & \multicolumn{3}{|c|}{$12 \mathrm{~h}$ after maceration } & \multicolumn{3}{|c|}{$1 \mathrm{~h}$ after maceration } & \multicolumn{3}{|c|}{$12 \mathrm{~h}$ after maceration } \\
\hline & $\mathrm{L}^{*}$ & $a^{*}$ & $\mathrm{~b}^{*}$ & $\mathrm{~L}^{*}$ & $a^{*}$ & $\mathrm{~b}^{*}$ & $\mathrm{~L}^{*}$ & $a^{*}$ & $\mathrm{~b}^{*}$ & $\mathrm{~L}^{*}$ & $a^{*}$ & $\mathrm{~b}^{*}$ \\
\hline 'Galicjanka' & 13.8 & 3.68 & -11.66 & 9.41 & 9.38 & -19.15 & 15.78 & 6.16 & -11.73 & 12.54 & 8.53 & -13.18 \\
\hline 'Hugin' & 17.06 & 4.37 & -14.12 & 11.83 & 8.64 & -21.63 & 14.95 & 6.21 & -12.84 & 11.97 & 7.11 & -16.51 \\
\hline 'Nero' & 14.63 & 4.51 & -16.63 & 7.13 & 10.1 & -23.55 & 14.13 & 5.19 & -12.98 & 11.48 & 5.76 & -17.49 \\
\hline 'Viking' & 14.89 & 4.64 & -16.33 & 6.96 & 11.37 & -24.04 & 14.34 & 4.93 & -13.15 & 12.73 & 5.49 & -18.44 \\
\hline Mean & $15.10 \mathrm{~B}^{\mathrm{a}}$ & $4.30 \mathrm{a}$ & $-15.19 a$ & $8.83 \mathrm{~A}$ & $9.87 \mathrm{~b}$ & $-22.09 b$ & $14.80 \mathrm{~B}$ & $5.62 \mathrm{a}$ & $-12.68 \mathrm{a}$ & $12.18 \mathrm{~A}$ & $6.72 \mathrm{a}$ & $-16.41 b$ \\
\hline
\end{tabular}

${ }^{\mathrm{a}}$ Explanation was displayed Tab. 1

Tab. 6. Characteristic of leaves of the four chokeberry cultivars

\begin{tabular}{cccc}
\hline $\begin{array}{c}\text { Characteristics } \\
\text { Cultivars }\end{array}$ & $\begin{array}{c}\text { Leaf area } \\
\left(\mathrm{cm}^{2}\right)\end{array}$ & $\begin{array}{c}\text { Length of leaf } \\
(\mathrm{mm})\end{array}$ & $\begin{array}{c}\text { Leaf width } \\
(\mathrm{mm})\end{array}$ \\
\hline 'Galicjanka' & $16.5 \mathrm{a}^{\mathrm{a}}$ & $62 \mathrm{a}$ & $43 \mathrm{~b}$ \\
\hline 'Hugin' & $12.8 \mathrm{a}$ & $83 \mathrm{~b}$ & $35 \mathrm{a}$ \\
'Nero' & $34.4 \mathrm{~b}$ & $87 \mathrm{~b}$ & $53 \mathrm{c}$ \\
'Viking' & $32.8 \mathrm{~b}$ & $84 \mathrm{~b}$ & $52 \mathrm{c}$ \\
\hline
\end{tabular}

${ }^{a}$ Explanation was displayed in Tab. 1

on the fruit surface ranged from 2.44 ('Hugin') to 7.51 ('Viking'). This parameter value determined for the pulp was significantly higher for all the cultivars and amounted to 16.63 (Tab. 4). Both juice and pulp color determined by the $\mathrm{a}^{*}$-parameter after 1 hour of maceration was alike and it had a similar value as the fruit surface (juice 4.30 pomace 5.62 skin 4.97). The process of 12-hour maceration changed the $\mathrm{a}^{*}$-parameter value in particular in the juice to 9.87. The color of a $5 \%$ concentrate from the chokeberry juice defined by the $\mathrm{a}^{*}$-parameter was much more intense and amounted to 63.8 (Gonzalez-Molina et al., 2008).

The fruit surface color defined by the $b^{*}$ parameter indicated the location on the axis between yellow and blue colors amounted to -5.21 . whereas in the pulp, it was -8.48 (Tab. 4). Values of $b^{*}$ were even higher in the process of maceration and they amounted to -15.19 after 1 hour and -22.09 after 12 hours. The highest value was observed in the samples consisting of fruits of 'Nero' and 'Viking' cultivars (Tab. 5). 
Tab. 7. Colour and greening index of the leaves of four chokeberry cultivars

\begin{tabular}{|c|c|c|c|c|c|c|c|}
\hline \multirow{3}{*}{ Cultivars } & \multicolumn{6}{|c|}{ Leaf color } & \multirow{3}{*}{$\begin{array}{l}\text { Green index } \\
\text { (SPAD) }\end{array}$} \\
\hline & \multicolumn{3}{|c|}{ upper leaf } & \multicolumn{3}{|c|}{ underside of the leaf } & \\
\hline & $\mathrm{L}^{*}$ & $a^{*}$ & $\mathrm{~b}^{*}$ & $\mathrm{~L}^{*}$ & $a^{*}$ & $\mathrm{~b}^{*}$ & \\
\hline 'Galicjanka' & $34.93 a^{a}$ & $-23.57 \mathrm{a}$ & $-1.26 a$ & $50.88 \mathrm{a}$ & $-3.26 a$ & $8.71 \mathrm{a}$ & $58.3 \mathrm{a}$ \\
\hline 'Hugin' & $33.30 \mathrm{a}$ & $-34.37 b$ & $-2.33 b$ & $52.96 \mathrm{~b}$ & $-4.66 b$ & $10.92 b$ & $73.1 \mathrm{~b}$ \\
\hline 'Nero' & $34.04 a$ & $-37.50 b$ & $-1.57 \mathrm{a}$ & $52.05 b$ & $-4.55 b$ & $10.48 b$ & $70.6 \mathrm{~b}$ \\
\hline 'Viking' & $34.15 a$ & $-38.38 b$ & $-1.12 \mathrm{a}$ & $52.78 b$ & $-4.04 b$ & $11.32 \mathrm{~b}$ & $72.4 b$ \\
\hline Mean & $34.11 \mathrm{~A}^{\mathrm{a}}$ & $-33.46 a$ & $-1.57 \mathrm{a}$ & $52.17 \mathrm{~B}$ & $-4.13 b$ & $10.36 \mathrm{~b}$ & \\
\hline
\end{tabular}

${ }^{a}$ Explanation was displayed in Tab. 1

It implies that 'Nero' and 'Viking' cultivars contain the highest quantity of fruit and pulp red- and blue-coloring substances. These cultivars have the darkest fruits which undoubtedly influence obtaining a dark juice. It is marked by the $L^{*}$ parameter the value range of which is from 0 (black) to 100 (white). The 'Hugin' variety is characterized by bright fruits and as a result-bright juice. Another experience showed that a 5\%-concentrate of chokeberry juice was significantly fairer where $\mathrm{L}^{*}$ parameter equaled 43.1 (Gonzalez-Molina et al., 2008). In turn $\mathrm{L}^{*}$ parameter of blackcurrant juice in comparison to the proper results was lower (the juice was darker) and amounted to 5.84 (Kalisz and Wolniak, 2007). Specific parameters (L* 16, a* 2.5, b* 1) of bilberry fruits (Vaccinium myrtillus) had similar values in an experiment conducted by Pasławska et al. (2010). For a few cultivars of apple trees the value of $\mathrm{L}^{*}$ coefficient ranged 35-50 for the blushed apple peel and 65-80 for the primary color (Rybczyński and Dobrzański, 2004).

To describe the cultivars under analysis more fully, a few parameters characterising the leaves were also presented. It was found that the leaves of the 'Viking' and 'Nero' cultivars were the largest (Tab. 6); they were characterised by a much larger surface area (32.8 and $34.4 \mathrm{~cm}^{2}$ respectively), they were also the broadest and the longest. Leaves of the 'Hugin' cultivar are equally long; however, they are narrow, which makes their shape lanceolate. In this way, these leaves have the smallest surface area, almost three times smaller than the leaves of the 'Viking' and 'Nero' cultivars. The leaves of cultivated cultivars are larger than those from wildly growing shrubs occurring in Russia; the length of leaves ranged from 41 to $55 \mathrm{~mm}$ and the width ranged from 23 to $34 \mathrm{~mm}$ (Skvortsov and Maitulina, 1982).

The colour of the leaves was also measured. Generally, the upper part of leaves is darker compared to the bottom, parameter $\mathrm{L}^{*}$ - top 34.11, bottom 52.17 (Tab. 7). In researches of Ozgur et al. (2011) fresh leaves of leek were brighter - $L^{*}$ 66.95. The upper leaf surface is also definitely greener (parameter $\mathrm{a}^{*}-33.46$ ) than the bottom of the leaf $\left(\mathrm{a}^{*}-4.13\right)$. The lowest value of this parameter was found on leaves of the 'Galicjanka' cultivar ( $\left.\mathrm{a}^{*}-23.57\right)$, which also had the lowest greening index (SPAD 58.3). In other cultivars, both parameter $\mathrm{a}^{*}$ and the greening index were at a similar level. The greening index is highly correlated with the content of chlorophyll, which is responsible for the green colour (Gregorczyk and Raczyńska, 1997). This is confirmed by the results obtained, leaves with the highest greening index were the greenest.

\section{Conclusions}

The data presented show differences in the quality and chemical composition of fruits and some morphological characteristics of both fruits and leaves of the cultivars being under analysis. Fruits collected from 'Hugin' cultivar shrubs are the smallest, which undoubtedly had an influence on the smallest amount of juice obtained from these fruits. Despite the low juice efficiency, fruits of the 'Hugin' variety generally had the highest content of the majority of the ingredients under analysis, both as regards the beneficial ones: soluble solids, titratable acids, polyphenol and harmful ones: nitrates and nitrites. The level of harmful nitrates is still on the allowable level. The chemical composition of fruits of the 'Nero' and 'Viking' cultivars, which was similar in the content of individual components, is at the lowest level. Chromatographic analyses (HPLC) and GAE showed that chokeberry fruits are a rich source of polyphenols, especially the 'Hugin' cultivar. In the fruits under analysis, there was the largest amount of cyanidin3-galactoside from among all polyphenols, which were determined - it constituted $50 \%$ of phenolic compounds. Beneficial health effects of polyphenols are an argument for looking for fruits rich in these compounds. The 'Nero' and 'Viking' cultivars have the largest amount of substances colouring fruits, pulp as well as red and blue juices. Fruits of these cultivars are also the darkest and the dark juice was obtained from them. The 'Hugin' cultivar was characterised by light-coloured fruits, and, as a result, by light-coloured juice. Maceration of fruit pulp resulted in a significant change of the colour of the juice obtained, it become darker and has a more intense blue colour. Shrubs of the 'Hugin' cultivar had long leaves; however, they are narrow and lanceolate. In this way, these leaves had the smallest surface area, almost three times smaller than the leaves of the 'Viking' and 'Nero' cultivars.

On the basis of these few characteristics which have been discussed above, it can be concluded that the ' $\mathrm{Vi}$ king' and 'Nero' cultivars are very similar both in respect of morphological features of their fruits and leaves and their chemical composition. The 'Hugin' cultivar, on the other hand, is fundamentally different from the other three cul- 
tivars. This is also confirmed by previously performed initially genetic investigations.

\section{References}

Ara V (2002). Schwarzfruchtige Aronia: Gesund - und bald "in aller Munde"? Flüssiges Obst 10:653-658.

Benvenuti S, Pellati F, Melegari M, Bertelli D (2004). Polyphenols, anthocyanins, ascorbic acid, and radical scavenging activity of Rubus, Ribes and Aronia. J Food Sci 69(3):164-169.

Espin JC, Soler-Rivas C, Wichers HJ, Garcia-Viguera C (2000). Anthocyanin - based natural colorants: A new source of antiradical activity for foodstuff. J Agric Food Chem 48:1588-1592.

Gonzalez-Molina E, Moreno D, Garcia-Viguera C (2008). Aronia-Enriched Lemon Juice: A New Highly Antioxidant Beverage. J Agric Food Chem 56(23):11327-11333.

Gregorczyk A, Raczyńska A (1997). Badania korelacji między metodą Arnona a pomiarami zawartości chlorofilu za pomocą chlorofilometru. Zesz Nauk AR Szczec 181:119. 123.

Hudec J, Bakos D, Mravec D, Kobida L, Burdova M, Turianica I (2006).Content of phenolic compounds and free polyamines in black chokeberry (Aronia melanocarpa) after application of polyamine biosynthesis regulators. J Agric Food Chem 54:3625-3628.

Jakobek L, Šeruga M, Novak I, Medvivovic-Kosanović M (2007). Flavonols, phenolic acids and antioxidant activity of some red fruits. Deutch Lebensm-Rundsch 103:369-378.

Jeppsson N, Niklas J (1998). Evaluation of black chokeberry, Aronia melanocarpa, germplasm for production of natural food colourants. Acta Hort 484:193-198.

Jeppsson N, Johansson R (2000). Changes in fruit quality in black chokeberry (Aronia melanocarpa) during maturation. J Hortic Sci Biot 75:340-350.

Jeppsson N (2000a). The effects of fertilizer rate on vegetative growth, yield and fruit quality, with special respect to pigments, in black chokeberry (Aronia melanocarpa) cv. 'Viking'. Sci Hort 83:127-137.

Jeppsson N (2000b). The effect of cultivar and cracking on fruit quality in black chokeberry (Aronia melanocarpa) and hybrids between chokeberry and rowan (Sorbus). Gartenbauwissenschaft 65(2):93-98.

Kähkönen MP, Hopia AI, Vuorela HJ, Rauha JP, Pihlaja K, Kujala TS (1999). Antioxidant activity of plant extracts containing phenolic compounds. J Agric Food Chem 47:3954-3962.

Kähkönen MP, Hopia AI, Heinonen M (2001). Berry phenolics and their antioxidant activity. J Agric Food Chem 49:40764082.

Kalisz S, Wolniak M (2007). Zmiany wybranych wyróżników jakościowych podczas przechowywania soków odtwarzanych z koncentratów. Żywność Nauka Technologia Jakość
5(54):203-212

Kawecki Z, Tomaszewska Z (2006). The effect of various soil management techniques on growth and yield in the black chokeberry (Aronia melanocarpa Elliot). J Fruit Ornam Plant Res 14:67-73.

Kolesnikov MP, Gins VK (2001). Phenolic substances in medicinal plants. Appl Biochem Microbiol 37:392-399. Translated from Kolesnikov MP, Gins VK. Phenolic compounds in medicinal plants. Prikl Biokhim Mikrobiol 37:457-465.

Konczak I, Zhang W (2004). Anthocyanins-more than nature's colours. J Biomed Biotechnol 5:239-240.

Kleparski J, Domino Z (1990). Aronia. PWRiL Warszawa. 100.

Koponen JM, Happonen AM, Mattila PH, Torronen AR (2007). Contents of anthocyanins and ellagitannins in selected foods consumed in Finland. J Agric Food Chem 55(4):1612-1619.

Krawiec P (2008). Effects of biostimulators on growth, cropping and fruit quality of chokeberry. Biostimulators in modern agriculture, Fruit Crops Warsaw 2008:42-48.

Kulling SE, Rawel HM (2008). Chokeberry (Aronia melanocarpa) - A review on the characteristic components and potential health effects. Planta Med 74(13):16251634.

Lehmann H (1990). Die Aroniabeere und ihre Verarbeitung. Flüssiges Obst 57:746-752.

Ochmian I, Oszmiański J, Skupień K (2009). Chemical composition, phenolics, and firmness of small black fruits. J Appl Bot Food Quality 83:64-69.

Oszmiański J, Sapis JC (1988). Anthocyanins in Fruits of Aronia Melanocarpa (Chokeberry). J Food Sci 53:1241-1242.

Oszmiański J, Wojdylo A (2005). Aronia melanocarpa phenolics and their antioxidant activity. Eur Food Res Tech 221:809813.

Ozgur M, Akpinar-Bayizit A, Ozcan T, Yilmaz-Ersan L (2011). Effect of Dehydration on Several Physico-Chemical Properties and the Antioxidant Activity of Leeks (Allium porrum L.). Not Bot Horti Agrobo 39(1):144-151.

Pasławska M, Stępień B, Jałoszyński K (2010). Changes in parameters of berry fruit colour caused by drying, storage and rehydration. Inżynieria Rolnicza 2(120):95-102.

Plocharski W, Zbroszczyk J (1989). Aronia fruit (Aronia melanocarpa Elliot) as a natural source of anthocyanin colourants. 1. Recovery of anthocyanins from aronia fruit by using alcoholic extraction. Fruit Sci Rep Skierniewice, Poland 16:33-39.

Rop O, Mlcek J, Jurikova T, Valsikova M, Sochor J, Reznicek W, Kramarova D (2010). Phenolic content, antioxidant capacity, radical oxygen species scavenging and lipid peroxidation inhibiting activities of extracts of five black chokeberry (Aronia melanocarpa (Michx.) Elliot) cultivars. J Med Plant Res 4(22):2431-2437. 
260

Rybczyńsk R, Dobrzański B Jr (2004). The evaluation of apple skin colour after storage. Acta Agrophysica 4(2):501-507.

Seidemann J (1993). Chokeberries a fruit little-known till now. Dtsch Lebensmitt Rundsch 89:149-151.

Skupień K, Oszmiański J (2007). The effect of mineral fertilization on nutritive value and biological activity of chokeberry fruit. Agric Food Sci 16:46-55.

Skupień K, Ochmian I, Grajkowski J (2008). Influence of mineral fertilization on selected physical features and chemical composition of Aronia fruit. Acta Agrophysica 11(1):213-226.

Skvortsov K, Maitulina YuK (1982). On distinctions of cultivated black-fruited aronia from its wild ancestors. Bulletin of the Central Botanical Garden, AN SSSR 126:35-40.

Smolarz K, Chlebowska D (1997). Porównanie owocowania aronii czarnoowocowej rozmnażanej generatywnie i wegetatywnie. Zesz Nauk ISK 4:111-118.

Smolik M, Ochmian I, Smolik B (2011). RAPD and ISSR methods used for fingerprinting selected, closely related cultivars of Aronia melanocarpa. Not Bot Horti Agrobo 39(2):276-284.

Strigl AW, Leitner E, Pfannhauser W (1995). Die schwarze Apfelbeere (Aronia melanocarpa) als natürliche Farbstoffquelle. Dtsch Lebensmitt Rundsch 91:177-180.
Strik B, Finn C, Wrolstad R (2003). Performance of Chokeberry (Aronia melanocarpa) in Oregon, USA. Acta Hort 626:439443.

Tanaka T, Tanaka A (2001). Chemical components and characteristics of black chokeberry. J Jpn Soc Food Sci Technol 48:606-610.

Walther E, Schnell S (2009). Black chokeberry (Aronia melanocarpa)-a special crop fruit. Zeitschrift für Arznei und Gewurzpllanzen 14:179-182.

Wilska-Jeszka J, Łoś J, Pawlak M (1991). Fruits as bioflavanoids sources. Acta Aliment Pol 17.

Wu XL, Gu LW, Prior RL, McKay S (2004). Characterization of anthocyanins and proanthocyanidins in some cultivars of Ribes, Aronia and Sambucus and their antioxidant capacity. J Agric Food Chem 52:7846-7856.

Würth K, Bonerz D, Will F, Patz C-D, Quast P, Hillebrand S, Winterhalter P, Dietrich H (2010). Anthocyanalterung in Säften und Konzentraten der Aroniabeere (Aronia melanocarpa). Deutsche Lebensmittel-Rundschau 106(10):549-559.

Zheng W, Wang SY (2003). Oxygen radical absorbing capacity of phenolics in blueberries, cranberries, chokeberries and lingonberries. J Agric Food Chem 51:502-509. 